\title{
CONSTRUCTION OF THE CONCEPT OF BUILDING POPULIST ECONOMIC LAW
}

\author{
Safrin Salam ${ }^{1 *}$, Rizki Mustika Suhartono ${ }^{2}$, Imron Rizki A ${ }^{3}$, Mustakim La Dee \\ ${ }^{1,2}$ Faculty of Law, Universitas Muhammadiyah Buton, Indonesia \\ ${ }^{3}$ Bone State Islamic Institute, Indonesia \\ ${ }^{4}$ Faculty of Law, Universitas Tompotika Luwuk Banggai, Indonesia \\ *safrinjuju@gmail.com (corresponding)
}

\begin{abstract}
The 1945 Constitution does contain the idea of political democracy and at the same time economic democracy. That is, in the highest power holder in our country is the people, both in the political and economic fields. All political and economic resources are controlled by sovereign people. However, in a democratic system built certainly not all of them are directly controlled by the people. The purpose of this research is to formulate the concept of populist economic law based on economic law in Indonesia and to understand the legal comparison between Islamic economic system and conventional economic system in the development of economic law in Indonesia. This research is normative legal research that is conducted by researching and studying the laws and regulations. The research approach used in this study is 2 (two) namely statute approach and conceptual approach. The results showed that the Concept of Economic Law Based on Populist Economy in Indonesia was built through 4 (four) principles of economic law, namely legal justice, legal certainty of benefits and affordable rules so as to realize the main goal of economic law, namely creating economic growth, balanced equality and welfare while the Comparison of Law Between Islamic economic system and conventional economic system in economic law development in Indonesia is Islamic economy based on sharia principles while conventional economy based on human will.
\end{abstract}

Keywords: Legal Construction; Comparison; Populist Economy; Conventional Economics.

\section{INTRODUCTION}

Indonesia as a legal country makes the law as the legal basis in the formation of laws of various sectors (Rizki A et al., 2021). One sector is the economic sector. Economics has an influence in the establishment of legal norms, especially related to economic law (Safrin Salam, Nurwita Ismail, Faharudin, Nuragifah, Erni Dwita Silambi, Shinta Nurhidayati Salam, Rosnida, 2020). The norms of economic law become one of the objectives of the state as stipulated in the constitution.

The idea of economic democracy is listed in both the explanation of the 1945 Constitution and article 33 paragraph (4) of the 1945 Constitution post-reform. In the history of the national economy, the spirit of economic democracy is often violated by the direction of the national economic system either towards the capitalistic economy or to the centralized economic system (Abbas T., \&Manan, 2005a). 
The 1945 Constitution does contain the idea of political democracy and at the same time economic democracy. That is, in the highest power holder in our country is the people, both in the political and economic fields. All political and economic resources are controlled by sovereign people. Philosophically this means that the economy stipulated in the 1945 Constitution needs to reflect the philosophy values of article 33 of the 1945 Constitution (Rofiq, 2020).

In a democratic system built certainly not all of them are directly controlled by the people. The populist economic system characterized by the enforcement of economic democratic justice and the provision of the weak is the foundation and at the same time as a means to realize social justice for all people which is the main pillar of economic democracy (Abbas T., \&Manan, 2005b).

Some of the main parts represented by its management to the state, in this case to (i) the MPR, DPR, DPD and the president in the affairs of the preparation of direction and formulation of official state policies, and (iii) to the president and other executive government institutions in the affairs of carrying out matters and policies of the state and (iii) indirectly to the judiciary in the matter of adjudicating violations of the direction and policies ne because it.

However, regardless of the delegation of authority from the sovereign people to the delegations of the people, both in the field of legislative, executive, and judiciary, the meaning of the sovereignty of the people as the highest power according to the system of political democracy and economic democracy can not be reduced under the pretext of the authority of the people has been handed over to officials. In the context of statehood, the sovereignty of the people is relatively absolute, although it must be given a limited meaning as the embodiment of the Omnipotence of God as recognized in the Third Paragraph of the Preamble to the 1945 Constitution. The system of government through the consensus of the people, by the people, and for the people has implications for improving the effectiveness and stability of the country (Hayat 2014).

The economy of a country requires a system. The chosen system must be able to animate the will and desire of most people in the country, because a system is unlikely to work properly if there is no need of the community itself towards the establishment of the system (Trialdi et al., 2003). According to Soeharsono Sagir, the economy of each country must run according to a certain system called the economic system. The economic system is the way a country regulates its economic life in order to achieve prosperity (Sigit 2012).

The type of economic system that Indonesia has as the basis for development over time is the populist economic system (SEK). In this system, sovereignty in the economic field is in the hands of the people, and therefore, the economy is closely related to the idea of economic democracy which is nothing but understanding the sovereignty of the people in the economic field. The target of the populist economic system is the liberation of people's lives from poverty, ignorance, dependence, unfair treatment, environmental damage, and a sense of vigilance in the settled future. Therefore, national development policy should not be out of the populist economic principle that according to soeharsono sager, reflected in the triple track development principle, namely pro-job and progrowth.

Economic problems are inseparable from human life. Whoever the person is, no matter where in the world, whatever the religion, will not be separated from this economic aspect. how not since, 
man was born, he already has many needs to be met. In general, economic activities can be divided into three kinds, namely production, distribution and consumption. Economic activities require a rule and also depend on labor, natural resources, management and so on. All of them form a system called economic activity and with the right economic system, then economic activities will succeed.

Throughout the course of human history there has been no system of human thought that has been proven to create absolute and perfect well-being. There are several eras in history that have been recorded as a glorious era in the welfare of humans, but the era did not last long, then the system was destroyed by itself by the makers and perpetrators, namely the capitalist and socialist system.

In general, the efforts to regulate / deregulate the locomotive "Economic Capitalization" is faced with the thick "Nationalism Indonesia, Indonesian Economic Populism" embraced by the constitution and the people of Indonesia (Satjipto, 1997).

So does the economic system that dominates the world today; capitalist economic system. The fact in the modern world reflects that this system has created such a radical gap among humans, where almost $20 \%$ of the world's population enjoys $80 \%$ of the wealth that exists on earth, while $80 \%$ of the world's population then contests the rest of the wealth. In some prosperous countries, people enjoy a life of sufficiency and exaggeration. While in many parts of the world, there is also a scream of hunger and poverty. In Indonesia itself, control has a legal system with modern character and various products of legislation that are deliberately prepared to initiate inefficient and unfair economic practices, so far it is still questioned the validity of its role and contribution to the recovery of the national economy that is limited by the storm of crisis precisely the law and apparatus and the professional law is currently in trouble (Sumali 2016).

On the other hand, Indonesian society which is mostly Muslim community has the Quran as a guide to his life. In the context of the broader meaning of Islamic economic law has existed since Muslims existed. This can be seen from the provisions of Islamic law that have been formulated in the form of legislation, namely Law No. 3 of 2006 concerning amendments to Law No. 7 of 1989 concerning Religious justice (Rusydi 2007). The presence of Law No. 3 of 2006 brings major changes in the regulation of property, business and sharia trade at large. Similarly, the Law in the economic system is Law No. 7 of 1992 on Banking as amended in law No. 10 of 1998 and Law No. 23 of 1999 concerning Bank Indonesi (Fitria 2016). With the development of Islamic economic law above shows the economic law has progressed rapidly so that it can be an alternative even become a legal choice in the regulation of economic law in Indonesia.

\section{METHOD}

This research is normative legal research that is conducted by researching and studying the laws and regulations. This research has qualitative character (Rendra Widyakso 2021) The research approach used in this study is 2 (two) namely statute approach and conceptual approach. The statute approach is done by studying all laws and regulations related to the legal issues that are being addressed. The conceptual approach goes from the views and doctrines that develop in the science of law. By studying the views and doctrines in the science of law, researchers will find ideas that give rise to legal understandings, legal concepts, and legal principles relevant to the issue at hand (Marzuki, 
2021). The data was obtained by researchers through the search for legal materials. For the statutory approach, researchers are looking for legislation related to arbitration arrangements. As for the concept approach researchers collect by conducting searches of legal books (treatises) and legal journals both national and international (Marzuki, 2021). The legal materials are then examined using existing approaches to answer legal issues that further provide a prescription on legal solutions to the legal issues discussed

\section{RESULTS AND DISCUSSION}

\section{A. Concept of Economic Law Based on Populist Economy in Indonesia.}

The findings of previous research on populist economic law through the perspective approach of conventional economic systems and Islamic economics have been widely done. Some of them are Azhar in 2017 with the title Between Islamic Economy and Conventional Economy. The findings of the research are economic system based on the provisions of the Qur'an and Sunnah, containing the value of brotherhood, love, appreciation for time, and togetherness. Therefore, the economic objectives in Islam are first to build a fair and equitable Muslim community with the widest opportunities, the second realizes a harmonious, united, peaceful and advanced economic life in a family atmosphere and then establishes a stable, prosperous, independent and independent economic life. While the characteristics of conventional economics are born based on human thinking that is always changing and impermanent, even always put aside aspects of ethics and morals depend interests what and who. (Fitria 2016) Similarly research from Zainal Abidin in 2012with the title Exploring the Concept of Economic Growth (Study on the contribution of Islamic economic system to conventional economic system). The results showed that the axiology approach in economic growth is based on value (sharia) or morals as the basis of economic life activity. Islam prohibits discriminatory behavior related to the distribution of income, Islam as Rahmah Li Al-Alamin with the aim of not only material welfare but welfare rohaniyah in an economic growth. Based on Azhar's research in 2017 and Zainal in 2012, it can be concluded that there are different legal sources in the arrangement between Islamic economy and conventional economy. In Islamic economy, The Koran and sunnah become the basis of economic formation while in conventional economy based on human thought and will itself so as to produce economic goals of difference.

Based on these findings, the differences in this study try to formulate (conceptualize the populist economy) which is studied through a comparative approach of Islamic economy and populist economy. The results of the comparison are adjusted to the economic needs of the People of Indonesia. Therefore, by promoting the concept of populist economy based on the study of Islamic economy and conventional economy. With the offer of this concept, the research contributes to the strengthening of article 33 paragraph (3) with a closer translation of the approach of the community itself, in addition to the research offers for the immediate establishment of the Populist Economic Law sourced from the People of Indonesia.

Economic law is a public law that especially regulates economic issues, in the public interest and the survival of the country, namely the Republic of Indonesia. thus it is closely related to national resilience and state politics (Sumantoro, 1986).

Therefore, the nature of Indonesian economic law must be able to protect the public interests, both the present interests, and the interests in the future. This law basically has a parallel relationship 
with society. Therefore the law has a function as a means of regulating the community (Salam, 2020). Therefore economic law should be able to look forward, based on past experience and current experience. Therefore, economic law must contain an early warning system (SIPERDIN) in its articles. SIPERDIN works on the basis of the introduction of indicators. These indicators are formulated in the form of a threat of punishment. One example that can be studied how the influence of economic law on the economic activities of the community at that time is the government of Indonesia intervened on the development of Islamic economy. Among the roles of the government in the establishment of Law No. 19 of 2008 on SBSN, Law No. 21 of 2008 on Sharia Banking, STATE-OWNED Enterprises established Sharia Banks, Law No. 41 of 2004 on Waqf, DSN MUI, Law No. 38 of 1999 on Zakat, Law No. 3 of 2006 on Religious Justice, KHES, The national movement of cash waqf is driven by President Susilo Bambang Yudhoyono whose management is handed over to BWI, PP No. 39 of 2008 Sharia Insurance on the Second Amendment to PP No. 73 of 1992 on the Implementation of Insurance Business, the establishment of the Directorate of Sharia financing in the Ministry of Finance, Implementation of the World Islamic Economic Forum (WIEF) in Indonesia (Faisal 2011).

If certain symptoms appear, as is the case in the Environment Act, then action must be taken, before more severe events occur. If it has exceeded certain limits, for example from environmental pollution to destruction then of course the punishment must be toughened. Thus, the Indonesian economic law has a clearer position. The republic of Indonesia is not a liberal country. Our country is working on transforming from a service economy into a modern economic structure. Until now this must be recognized, that in many areas of the economy, we cannot directly connect with the buyer in Europe or America. There are many commodities that must be sold through our Singapore in both places.

This is due to our inability in certain areas, where we have not been able to meet the conditions. Examples are shipping, processing and so on. Another reason is, because part of us is still a society with a service economy, as can be seen in daily life, brokers and liaisons are a common symptom in Indonesia. in the villages the farmers can not sell their livestock directly, but must go through intermediaries in central Java and East Java called blantik. Similarly, in other fields of service economics businesses can not be directly related to the economic system of money, because it does not know each other's norms, while intermediary traders have a quality and understanding of these two economic systems.

So to solve this problem, it is appropriate that there must be a concept of Indonesian law based on populism to protect the rights of the people (people's sovereignty), Juajir Sumardi in a public lecture "Economic Law" said that in the development of economic law (Al-fatih 2020) must have a vision, objectives (mission) and main goal as in the following framework. 


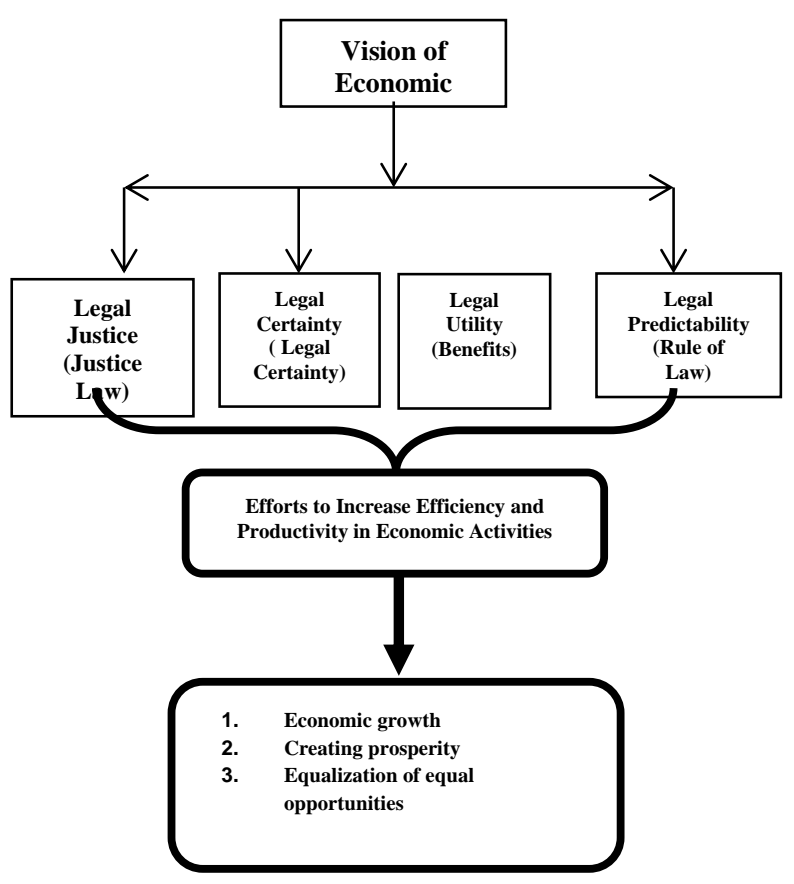

Figure I. Concept of Economic Law Based on Populist Economy

Based on the concept chart of economic law by juajir sumardi it is clear that there is a concrete relationship between economics and law in building Indonesian law in Indonesia, concretely the science of law regulates human behavior while economics studies human behavior in meeting its needs, based on that there is a strong relationship between economics and law. based on the concept of economics gave birth to legal principles, namely:
a. Litigation costs
b. Property rules
c. Strict liability
d. Non monetary sanctions
e. Efficient-breach

Based on the basic concept of economy of law, basically human beings as homo economies, meaning that in taking action to meet their economic needs, they put forward economic value with economic reasons and considerations. In doing all that, people are always given the option to get economic satisfaction that is ultimately shown to increase prosperity to improve people's standard of living. Based on the concept of Economy Analysis of law, the purpose of economic law development is the fulfillment of the needs meaning that the existence of the economy is to help the community in meeting its economic needs both now and in the future, the fulfillment of the needs of people's lives makes the economic law visionary must be able to bring also the welfare of the fulfillment of the economic value of society so that thus a balanced equalization of opportunity is formed because economic law is built on its role. Therefore, there are 3 (three) basic elements in economic considerations, namely (Irwansyah 2013a): 

a. Value
b. Utility
c. Efficiency

These three elements must exist in building the basic concept of economic law that justice means that justice can become an economic standard. On the contrary, if there has been a fair economy, then the effective law is:
a. Has value (enforceable application)
b. Effective (works as intended)
c. Efficient (enforcement for the welfare of the people)

Based on this, Indonesia economy can learn from the economy in European countries such as Germany, Netherlands, Belgium and a number of Scandinavian countries that are the type of countries that adhere to the welfare state with the principle of social market mechanism capitalism. In this principle, the balance between market mechanisms and social harmony is considered two main principles. Balance and taste in society can be built through three steps, namely (Irwansyah 2013b):

a. Cooperative business groups and communal property rights of the community are protected and given the opportunity to master and manage productive resources;

b. The progressive tax burden is determined high for the ease of redistribution of the deposit rate;

c. The government encourages the creation of tri-partite relationships between need or labor (Al-Fatih, Ahsany, and Alamsyah 2020), employers and the government through the implementation of collective labor agreements (Anggraeny and Al-Fatih 2020).

In this social market economic system, individual motivation is balanced with the principle of common interest. Economic activities are driven by market mechanisms controlled by the government towards an efficient, but equitable market economy as referred to in article 33 paragraph (4) of the 1945 Constitution. Ownership of production factors by individuals is limited by laws, customary laws and norms of public interest, public ownership and communal interests. The role of the private sector is not limited as long as it is not related to the production branches that are important to the state and control the lives of the people. The role of the government, not only as a regulator, but also take the necessary actions and even become a direct actor in the event of negative externalities, failures in market mechanisms, economic inequality, or social inequality. The value system imposed is a moral and social responsibility. All of that is shown to advance and empower all economic actors in a balanced and sustainable manner towards quality economic growth, namely economic growth that ensures fair equality. 


\section{B. Comparison of Law Between Islamic Economic System and Conventional Economic System in Economic Law Development in Indonesia.}

In philosophy of science, science or science is divided into three parts, namely ontology, epistemology and axiology. Ontology is everything related to the formation of science. Epistemology is the meaning of science that is about the ins and outs of science itself, what its abilities and limitations are. Axiology is a useful aspect of science, namely matters related to efforts to improve the welfare of life (Hadi 2010).

Judging from the ontological aspect, conventional economics uses the foundation of positivism philosophy based on empirical experience and study by not associating the instructions of god (secular). In a secular economy, pleasure or happiness is merely happiness in the world alone and is highly materialistic. They do not see that what is done will have an effect on the Hereafter. While the Islamic economy, which is the main guide is the guidance of Allah in the form of revelation (AlQuran, Al-SUnnah, Qiyas, Ijma and Ijtihad and kauniyah verses). In conventional economics, encouraging economic activities is self interest. It means what is done solely for personal gain. While in Islam that becomes the driver is the will of Allah (god interest) that is in order to serve and seek the pleasure of Allah SWT (Hadi, 2010).

Epistemologically, the economy comes from okonomiyaki (Greece). The word comes from two oikos words meaning household and nomos means rule. So economics is a household science, which in English is referred to as economics. Based on the terms of economic scope as stated above, Islam as a religion that regulates all aspects of life, of course has a way to economy. In this regard Yusuf Halim al-Alim defines Islamic economics as the science of the laws of applicative sharia taken from detailed evidences related to finding, spending, and how to spend wealth. This definition shows the focus of Islamic economic studies is to study Islamic society that follows the rules of Islamic sharia.

Islamic economic understanding has a principle derived from the Qur'an and Hadith. Islamic economics as a discipline has an epistemological foundation. Islamic economic epistemology means a review of Islamic economic sources including methodology and scientific truth. The epistemology of Islamic economic law requires ijtihad to use ratio reasons. Epistemology of Islamic economic law using deduction method (Arwani, 2017).

Judging from the axiological aspect of Islamic economic objectives is that every human activity is based on the service to Allah in order to carry out the task of God to prosper the earth as a caliphate, then in the economy Muslims must celebrate harmony and preservation of nature. Islamic economics here refers to an economy that is supported by Islamic teachings, while the Islamic political economy here refers to the interaction between Islamic economics and Islamic politics as well as the implications of each other's influence on each other (Mohd Syakir, 2014).

Islamic economics holds that welfare is not only a matter of material economic distribution but also concerns non-material elements and other fields. Therefore, welfare in the economic field will be able to be established along with the establishment of welfare in other areas that serve to support and strengthen each other. The Islamic economy requires its followers to carry out the whole 
teachings of Islam in all aspects of its life. The consequence of this concept is that welfare should be seen as the embodiment of God's command to his servants. So that welfare is a continuous effort of mankind to do its best, both to God and to fellow human beings based on the guidance of Islamic teachings (Agung, 2014).

Economic system is a unified mechanism and decision-making institution that implements decisions on production, distribution and consumption in a region or region. The economic system is likely to put pressure on certain property rights, such as individual property rights, social property rights and state property. An economic system may have unique methods of decision making. For example using centralistic, decentralist or combination methods of both. The Islamic economic system will include a unity of mechanisms and institutions that will be used to rationalize Islamic economic thinking and theories in production, distribution and consumption activities. Follow the comparison concept of Islamic economics and conventional economics (capitalism, socialism).

Tabel 1. Economy Islah by P3EI. UII. For cooperation with BI

\begin{tabular}{|c|c|c|c|}
\hline Indicators & capitalism & Socialism & Islam \\
\hline $\begin{array}{c}\text { Properties of } \\
\text { ownership }\end{array}$ & $\begin{array}{l}\text { Absolute ownership } \\
\text { by man }\end{array}$ & $\begin{array}{c}\text { Absolute ownership } \\
\text { by man }\end{array}$ & $\begin{array}{c}\text { God is the absolute } \\
\text { owner, while man has } \\
\text { limited ownership } \\
\text { rights }\end{array}$ \\
\hline Utilization rights & $\begin{array}{c}\text { People are free to use } \\
\text { it }\end{array}$ & $\begin{array}{c}\text { People are free to use } \\
\text { it }\end{array}$ & $\begin{array}{c}\text { Human utilization } \\
\text { follows the provisions } \\
\text { of God }\end{array}$ \\
\hline Ownership priority & $\begin{array}{l}\text { Individual property } \\
\text { rights are upheld }\end{array}$ & $\begin{array}{l}\text { Individual property } \\
\text { rights are upheld }\end{array}$ & $\begin{array}{c}\text { Individual and } \\
\text { collective property } \\
\text { rights governed by } \\
\text { religion }\end{array}$ \\
\hline $\begin{array}{c}\text { The role of individuals } \\
\text { and countries }\end{array}$ & $\begin{array}{l}\text { Individuals are free } \\
\text { to utilize resources }\end{array}$ & $\begin{array}{l}\text { Countries governing } \\
\text { resource utilization }\end{array}$ & $\begin{array}{c}\text { There is a } \\
\text { proportional } \\
\text { obligation of } \\
\text { individual-state } \\
\text { communities }\end{array}$ \\
\hline $\begin{array}{c}\text { Distribution of } \\
\text { ownership }\end{array}$ & $\begin{array}{c}\text { Based on market } \\
\text { mechanisms }\end{array}$ & $\begin{array}{l}\text { Based on the role of } \\
\text { the government }\end{array}$ & $\begin{array}{l}\text { Partly regulated by the } \\
\text { market, the } \\
\text { government and } \\
\text { directly by the Quran }\end{array}$ \\
\hline $\begin{array}{c}\text { Utilization } \\
\text { responsibilities }\end{array}$ & $\begin{array}{c}\text { Economic-technical } \\
\text { accountability to } \\
\text { oneself }\end{array}$ & $\begin{array}{l}\text { Accountability to the } \\
\text { public economically- } \\
\text { technically only }\end{array}$ & $\begin{array}{l}\text { Accountability to the } \\
\text { self, public and god in } \\
\text { the world and akherat. }\end{array}$ \\
\hline
\end{tabular}


In Islamic view, the absolute owner of the whole universe is Allah swt, while man only bans His trust. God created the universe for Himself, but for the sake of means of life for mankind in order to create prosperity and prosperity. Man is given the right to own and rule the universe as long as it is in accordance with the means of acquisition and method of use that has been determined by god. Thus the existence of property rights carries consequences of the obligation to use them. In the end, this property must be answered before the court of God in after life.

Based on the explanation can be concluded under the origin of the establishment of the Islamic economic system departs from the awareness of ethics, an ethical economy, while other economic systems, both capitalism and socialism, depart from the interests (interests) the rights of individuals and people in a fair balance. In the paradigm of Islamic economic concept, there are three madhabs that have different views, namely: First, madhab Bagir al-Sadr who sees that economics can never be in line with Islam, because both come from contradictory philosophies. Therefore, this madhab uses the term ijtihad, not Islamic economics. Second, mainstream madhabs who think that, like conventional economies, resource scarcity is the cause of economic problems. Third, the Critical Alternatives madhab argues that critical analysis should not only be done on socialism and capitalism, but also on the Islamic economy itself (Fadlan, 2013). While capitalism and socialism were initially communicated as representations of the economic behavior of certain countries, for example capitalism was mirrored by Americans and socialism was reflected by the Soviet Union.

Capitalism is inspired by the need for the freedom of each individual to meet his needs gar the welfare of society is achieved. It is assumed that every human being is individualistic rational so that market freedom will result in maximum social welfare. Market mechanisms metaphorized by invisible hand will regulate the course of the balance between supply and demand in the market. Smith writes "we can eat fruit not because of the kindness of the baker, the drinker or the butcher, but because of the selfishness that is within them. We do not expect their love for others, but rather their love for themselves.' Freedom of economic behavior of every individual, market and government policy.

On the other hand, the economy of socialism has the purpose of mutual prosperity. Philosophically it is how individual attitudes together acquire well-being. The realization of socialism put the humanitarian element at its highest, higher than the means of production. If the production tool mastered man, then man will lose the essence of humanity. It will be part of the production tool so as to make human life like a machine as a "life" production tool. Until finally the production tool keeps people from knowing its function as a human being.

\section{CONCLUSION}

The concept of a populist economic system is realized through the implementation of four values, namely legal justice, legal certainty, benefits and clear rule of law in the implementation of the economic system in Indonesia. The goal is to increase efficiency and productivity that is balanced and fair. These four values are derived from a sense of human consciousness but must certainly be framed according to the interests of balance between one and the other. 


\section{REFERENCES}

Abbas T., \& Manan, W. K. 2005a. "Demokrasi Politik, Demokrasi Ekonomi Dan Sistem Ekonomi Kerakyatan." Jurnal Sosial Dan Pembangunan 21(3):429-39.

Abbas T., \& Manan, W. K. 2005b. "Keterkaitan Antara Demokrasi Politik, Demokrasi Ekonomi Dan Sistem Ekonomi Kerakyatan." MIMBAR, Jurnal Sosial Dan Pembangunan 21(3):429-39. Agung, P. 2014. “Kesejahteraan Dalam Ekonomi Islam.” Justitia Islamica 11(1):21-42.

Al-fatih, Sholahuddin. 2020. "Economic Analysis Relationship in Determining The Size of Parliamentary Threshold in Indonesia." Indonesian Journal of Law and Policy Studies 1(2): $152-58$.

Al-Fatih, Sholahuddin, Fachry Ahsany, and Ahmad Faiz Alamsyah. 2020. "Legal Protection of Labor Rights During the Coronavirus Disease 2019 (Covid-19) Pandemic." Jurnal Pembaharuan Hukum 7(2):100-115.

Anggraeny, Isdian, and Sholahuddin Al-Fatih. 2020. "Kata Sepakat Dalam Perjanjian Dan Relevansinya Sebagai Upaya Pencegahan Wanprestasi.” DE LEGA LATA: Jurnal Ilmu Hukum 5(1):57-66.

Arwani, A. 2017. "Epistemologi Hukum Ekonomi Islam (Muamalah)." Religia 15(1).

Fadlan. 2013. "Paradigma Madzab-Madzhab Ekonomi Islam Merespon Sistem Ekonomi Konvensional." Al-Ihkam: Jurnal Hukum Dan Pranata Sosial 7(1):156-77.

Faisal, L. 2011. "Politik Ekonomi Islam Dalam Pembangunan Ekonomi Nasional Indonesia." Asas: Jurnal Hukum Dan Ekonomi Islam 1-11.

Fitria, Tira Nur. 2016. “Kontribusi Ekonomi Islam Dalam Pembangunan Ekonomi Nasional.” Jurnal Ilmiah Ekonomi Islam 2(3):29.

Hadi, Abd. 2010. Dasar-Dasar Hukum Ekonomi Islam. Surabaya: Putra Media Nusantara.

Hayat, H. 2014. "Korelasi Pemilu Serental Dengan Multi Partai Sederhana Sebagai Penguatan Sistem Presidensial." Jurnal Konstitusi 11(3):468-91.

Irwansyah. 2013a. Bahan Kuliah Program S2. Makassar: Fakultas Hukum Universitas Hasanuddin Makassar.

Irwansyah. 2013b. Power Poin 2013. Makassar: Fakultas Hukum Universitas Hasanuddin Makassar. Marzuki, Peter Mahmud. 2014. Penelitian Hukum. Jakarta: Kencana Prenada Media Group.

Mohd Syakir, M. R. 2014. "Mencari Ekonomi Holistik : Antara Ekonomi Islam Dan Ekonomi Politik Islam.” Pp. 321-346" in Konferensi Internasional Pembangunan Islami - I.

Rendra Widyakso, Fifik Wiryani. 2021. "Analisis Pelaksanaan Putusan Peradilan Agama Terhadap Nafkah Perceraian Dalam Perspektif Hukum Nasional Dan Hukum Islam Bagi PNS.” Audito Comparative Law Journal (ACLJ) 2(2):86-109.

Rizki A, Imron, Rizki Mustika Suhartono, and Safrin Salam. 2021. "Implementation of State Administrative Court Decisions: Conception, and Barriers." Musamus Law Review 3(2):49-57.

Rofiq, Noor Fajari. 2020. "Reconstruction of Prostitution Law in Perspective of Religious Norms and Renewal of Criminal Law." Audito Comparative Law Journal (ACLJ) 1(2):105-12.

Rusydi, M. 2007. "Formalisasi Hukum Ekonomi Islam: Peluang DanTantangan ( Menyikapi UU No . 3 Tahun 2006 )." Al-Mawarid (3):1-2. 
Safrin Salam, Nurwita Ismail, Faharudin, Nuragifah, Erni Dwita Silambi, Shinta Nurhidayati Salam, Rosnida, Sulaiman. 2020. Perkembangan Filsafat Hukum Kontemporer. Sidoarjo: Zifatama Jawara.

Salam, Safrin. 2020. "Rekonstruksi Paradigma Filsafat Ilmu: Studi Kritis Terhadap Ilmu Hukum Sebagai Ilmu." Ekspose: Jurnal Penelitian Hukum Dan Pendidikan 18(2):885-96.

Satjipto, Rahardjo. 1997. "Pembangunan Hukum Di Indonesia Dalam Konteks Global." Jurnal Perspektifle 2(2):1-10.

Sigit. 2012. "Sistem Perekonomian Di Indonesia."

Sumali, S. 2016. "Peran Hukum Dalam Pemulihan Ekonomi Di Indonesia." Jurnal Bestari 34(1).

Sumantoro. 1986. Hukum Ekonomi. jakarta: UI Press.

Trialdi, Ledi, I. Kadek Dian Sutrisna A, and Joko Arif. 2003. "TRANSFORMASI SISTEM EKONOMI INDONESIA MENUJU SISTEM EKONOMI SOSIALISME PASAR.” Buletin Ekonomi Moneter Dan Perbankan 2(1):83-97. 